\title{
A Curriculum of Difficulty and 'The Anger in Our Miss Maple' : The Story and The Commentary
}

\author{
Leah C. Fowler \\ The University of Lethbridge
}

\section{The Anger in Our Miss Maple: The Story}

\author{
"Matthew." \\ "Here." \\ "Mary." \\ "Present, Miss Maple." \\ "Mark." \\ "Present." \\ "Luke?" \\ "Yuh ... here." \\ "Miriam?" \\ "Uh-huh." \\ "Miriam, what was that?" \\ "Here, Mzzzzzz. Maple.” \\ "That's better. John. John?" \\ “..."
}

"Ruth?"

"Ya. Here ... Missssss Maple."

"John! You ARE here. I called your name. Are you with us or against us? It is common courtesy to speak when spoken to, people."

"How come ya always call us "people" when you only mean one of us," sneered Luke, who was the brightest in this class of English 17, and whom Miss Maple privately scorned because she knew he wanted to get into medicine but felt certain he would be lucky if he could pass a first aid course.

"Luke, I wasn't speaking to you. John, answer me." 
"What? Okay, okay, so I'm here. Ya can see that. Don't get yer . . . uh self in a twist."

"Peter?"

"Yes."

"Esther."

"Yeah, whatever."

“"Present, Ms. Maple' would be nice. Timothy?"

"Present, Miss Maple, sir."

“Okay, okay. David, Sarah, Joshua ... you are all here too. All right, class, I want to begin a new section of study. We just finished the novel Hunter in the Dark and now..."

“That guy was a faggot.” John took a long "drag” on his slurpee and looked over the edge of the huge, waxed-cardboard rim at Miss Maple.

"John, that'll be enough. Every time you see a male character deal with hard human problems and show a little tenderness of feeling in friendship, it doesn't mean he is a homosexual. Although there are plenty of wonderful people who do happen to prefer their own sex. It is time you opened your horizons a bit, my boy. How do you think you would react if you were told that you were dying?"

"I ain't dying. I use safe sex, eh?” and he enjoyed the raucous, if nervous, laughter of the class.

"Good one, John. Hey! Yeah. "Rad" point is, how come we do always read this candy shit in school? It's such "Little-House-on-the-Prairie-Walton's-Brady-Bunchhomey do-do." I mean take a look around . . . life ain't like that . . it just ain't.” Mary snapped her gum, bathed her teeth in fresh air, and blew John a kiss.

"Well, we have finished the book now anyway, and we are going to start a new section today, as I said, and I think you will like what I have planned. Usually I have taught poetry using the textbook but this time..."

Matthew wadded a blank piece of loose-leaf paper and "made a basket" into the garbage tin at the front of the room. "Two points. D'jou guys see that? Poetry--like it? Poetry? NOT! Nah, I don't think so, Teach.” 
"Let me finish, peop-- class. What I would like you to do is each choose a group or musician whom you like and pick three or four of their songs to bring to class. You write out the lyrics, the words to the song, and I'll make copies for us to study. We will use the poetry that is being listened to and written now as our texts to study together."

"Yeah, that's "rad." Maryanne Faithful . . . I am bringing Maryanne Faithful, a little "snatch" of music," Peter chuckled lewdly.

“Nah, Corrosion of Conformity's better," Esther whined.

"We have twelve people left in the class. I want four songs from each of you with no overlap."

"Where's the sign-up sheet; I'm doing Eminem everybody, so butt out." Mark got up and seized a piece of foolscap from the teacher's desk. He wrote his name at the top in capital letters and then slouched over to John. "Your "quick-pik-double-dip," man, winner takes all."

Miss Maple strode over to John and reached for the paper, but he whisked it neatly out of her grasp. She glared at him and backed up to the front of the room. "It is fitting that you should have the "fool's cap," John. Keep it then."

Ruth tilted backward on the two back legs of her chair and leered, "Oooooh Schweeeeet, Studley-you-da-man, you have just been insulted."

"Shut it, bitch."

"All right; that will be ENOUGH! Spelling test. Get some paper. There will be words from the novel we just finished. It's worth fifty marks. Your report cards are in a week. If you cannot conduct yourselves like Grade 10 human beings, then we will conduct it like an elementary class until you can begin to behave like adults."

"I don't have any paper."

"Then borrow some, Esther."

"I don't have a pen."

"Then cut yourself and use blood. First word: leukemia. Second word: melancholia. Third word: disciple. Fourth word: labor."

"Could d'ja slow down, jeez."

"No. I can speed up: anachronism-tedious-Neanderthal-irritable-stupidityprejudice-dyslexic-neurasthenia-wrath. ..." 
"Miss Maple ... Miss Maple. We never took these words."

"Yes, well. You are taking them now; you will need to know what they mean in your little lives, that's for sure."

"Hey, Miss Maple. Hey. . . what is this. . you on the 'rag'?"

"Fifty marks: violence, bile, venom, slaughter, volatile," and so she dictated and so they wrote, or tried to, in a frightened and eerie new silence until the bell rang for a ten-minute break before next class.

The warning bell signaling five minutes to the start of the next, the third, class of the morning sounded through the halls of Isis Banes Composite High School, but our Miss Maple would be late again. Since September first, eight months ago, at 10:38 every weekday morning, our Miss Maple had been vomiting her diligently prepared breakfast. Then she'd brush her teeth, gargle, compose herself, and march back to class with new confidence.

She had not been vomiting from early pregnancy as Linda Knight did before the first class, or from alcoholism as Dylis Framley did before second class. As nearly as she could tell, our Miss Maple had been vomiting from rage--that kind that erupts from lack of control and lack of hope.

Until this morning though, provoked beyond her usual mask of professional decorum, it had not really occurred to her that she could actually change things and had even resigned herself to the fact that matinal purging was simply to be one of her personal aspects in the job of teaching English to a new species of adolescent cretins.

This morning, as she lifted the lid on the toilet to be sick, she read scribbled in permanent-black-felt pen "Fuk You, Mis Mapel." The entire contents of her stomach projected themselves unbidden into the porcelain bowl. Those words scrawled in learning-disabled graffiti unleashed something in her that had been building over twenty years of marking illiterate papers and lesson planning, cafeteria supervision and PTA meetings, teaching remedial reading and interminable English classes half full of students on the ten-year plan for high school.

So when our Miss Maple returned, albeit just a little late, to the third class of English 17 on that Wednesday morning after the bathroom episode, she was a changed 
woman, and well-armed. She had lesson-planned her next class over the recess, but it was planned as none ever had been planned before in her teaching career.

They were crowded out in the hall around her locked classroom door and began the harassment the minute she came into view.

"Yo! Teach! You're a little late for class. Thirty-five push-ups, and go to the office for a late slip, and you're suspended for the day and don't you ever come back to this class late again, young lady. Huh? Huh? Isn't that what you'd say, teach? Huh? Am I right? Take your own, Teach."

Miss Maple smiled and shifted the bundle in her arm and slowly unlocked the door. The disciple-dozen of her "in loco parentis" charges, for the second of their double period with her that day, ambled and scurried, shoved and slouched their way toward disabled desks. Miss Maple watched their faces carefully, one by one, one arm on the bundle and not moving away from her desk.

"What's doin', Teach?"

With a few efficient brush strokes, Miss Maple erased the neatly printed agenda and the entire set of notes from the board, leaving a chalky green open wall space below artists' renditions of the classical authors.

“Nothin', pupes." She liked that. It made her think of the metamorphosis pupa stage of caterpillars unfinished in their development, only to become moths. She'd be the first in line to light the candle for them, because clearly, cursing the darkness hadn't worked. She smiled again, and closed the classroom door and locked it with her key.

The twelve students shifted nervously and improved their posture as Miss Maple shoved the teacher's large desk up against the only door to the room and placed the large metal garbage can on top of the desk, right in the middle.

“Oh, I get it, ” Joshua said, "We done so terrible on our assignments you're gonna throw 'em in the garbage, right?"

"NOT! Wrong as usual, Joshua."

The lad was hurt because he was sure Miss Maple had liked him and he was confused by her strange tones and words. He glanced out the window and was temporarily comforted by the warm yellow glow of the early morning spring sunshine. 
Miss Maple, still smiling serenely, dumped all the papers, file folders, memo, letters, journals, and handouts into the huge gunmetal-gray can.

"We are going to have Spring today, a new beginning and a little poetic, mythology lesson, which you will always remember."

For the first time during the whole school year, that April morning she had the attention of every student in the class. She opened the side drawer of the desk and emptied the contents of seven butane lighter tins (confiscated over the course of the years from her students with pyromaniacal tendencies) over the papers, into the garbage can. She wrote the single word "Phoenix" on the front board, began to hum melodiously, sat on the desk with her left arm around the garbage bin, and lit a match to the paper nest. 


\section{A Curriculum of Difficulty and "The Anger in Our Miss Maple": The Commentary}

Teachers must be careful with the stories they tell and write. Honourable teachers must be careful because stories can be dangerous in their teachings. Simple little stories aren't. Stories seduce: they build desire -- to know what happened, to watch who, to visualize where and when, to make meaning about how, and to more deeply understand why. There is a loss of innocence each time the teller tells, the listener hears, the reader reads. Stories educate because they lead us to see, know, become something else as the heart matures or withers, as the mind connects or disengages.

Stories have power but I want to make a distinction between a story and a narrative. Traditional narrative includes not only the story, but also the teller, the told, the context and conditions of the story telling, and the reasons and intentions for narrating. In addition to this I want to make a case that narrative research in education has become a curriculum of difficulty and to suggest there is a need to "trouble" our assumptions about such research.

I am a writer, a teacher of teachers, a teacher of language arts and science, a narrative researcher interested in difficulty in teaching at the site of the teacher. I am compelled by narrative as a meaning-making life process which is full of questions and difficulty. More specifically, I have written and listened to and studies many narratives about teaching. These narratives all become, in a crass reductionist labelling, data as I research teaching difficulties. The reasons, intentions, and opportunities for these kinds of narrative have proliferated in educational research as we try to make sense of an insane, problematic, hostile, complex world, and attend to what needs learning in the human enterprise. I believe narrative is an important temenos for examining difficulty, especially in teaching [temenos is the Greek for crucible which holds dangerous, hot, or unstable substances]. But, I am concerned about what passes for research in the narrative domain. Writing stories does not, for me, constitute narrative research, although narratives do teach and do contain curricula of difficulty.

The need for a more thoughtful, analytical, interpretive approach to narrative research has come to my attention because of my own work. In the past three years I have had graduate students unknown to me front up to my office door to say: "I want to do narrative research and I heard you do that - will you work with me?" 
We often have a brief conversation about their intentions for choosing a narrative method. Sometimes they come with a story they have written about a difficulty with a student, a parent, a co-worker, an administrator and they have become attached to the story and want to use it because of the power it has for them. I am becoming increasingly concerned about what is happening with narrative research in education. The narrative knot for researchers does not constitute the whole of the research. Stories as data are sufficient perhaps as stories, but they are not sufficient as research and are not inherent analyses of a compelling research question. The mis/use of narrative in education research has me worried.

Narrative research can be an authentic, autobiographical project [see the work of curriculum reconceptualists such as Greene, Pinar, Grumet] which requires ethical stewardship, literary skill, intelligent attention, erudite writing craft, and a persistent, sentient, honest hermeneutic vision on the part of such a researcher. But narrative research also can be a narcissistic, banal project which reveals self-interest, lack of scholarly discipline, dishonest theft of the experiences of one's "research subjects", and simplistic, stagnating thought. In such "research" if theory is derived at all, it belongs in the popularized pap of advice to teachers or of recipes for teaching success, which serves to trivalize real difficulty in teaching and vilify the other in essentialist ways rather than moving to a reflective practice of understanding and moral participation in the educational enterprise.

For five years in my own doctoral work I wrote stories of teaching (I wrote stories for years before that as a creative writer), and the resulting narratives "troubled" my practice, my identity, my thinking and my being. As a result of the narrative research that followed those stories, I have reconstituted my own teaching and continue to understand and learn and grow from my life work. I continue to learn that narratives are a curriculum of difficulty. In my research, I want to explore that curriculum as a curriculum, thinking about the intentions and goals and learning outcomes of narrative research, the resources and material and display of it, the activities of narrative projects, and finally assessment and evaluation that can be made about narratives and the kind of knowledge that interpretive research can construct and deconstruct. 


\section{Developing a writer's memory and perception}

Growing up on Central Alberta's prairies in the 1950's and 1960's, I learned a vast range of plot lines; I studied the patterns, connections, historical detail, cultural niches and social relations of people's real and possible lives, mine among them (Kerby, 1991; Polkinghorne, 1988). In the landscapes of my childhood, I developed a writer's memory and perception, began to cultivate a writer's memory of paying attention to detail, attuned to the smallest particle of soil or tiniest insect, noticed infinitesimal changes in light waves of the late evening prairie summer sun on tree sap. A five-degree drop in temperature or a fifteen-degree shift in wind direction could foreshadow so much. A baby's bonnet color being pink or blue; a chickadee with its neck broken, splayed below delphiniums under the dining room window; only the mouth of a face smiling while the eyes remained cold; a phone call hung up too quickly; a restrained outflow of breath: as a child I noticed how any of these had the power to alter story plots and change everything in a twinkling of an eye. As a child I needed to pay attention to clues. Everything depended upon what one was able to notice. Very early--intuitively one might say--I developed the eye of a researcher and the ear and the voice of a storyteller.

Most of my adolescent reading was fiction, which I then naively understood as neither real nor factual, yet in which I recognized the human truths of relationship, understanding, affect, pattern, motivation, and power. Most importantly for this work, I developed a strong ability to pay attention to story. Narrative truth became a kind of measuring stick for me about what really was going on in the world, in my own life, in the lives of those I knew, and in the lives of more public figures. As Weil writes:

There is something else which has the power to awaken us to the truth. It is the works of writers of genius. .. . They give us, in the guise of fiction, something equivalent to the actual density of the real, that density which life offers us every day but which we are unable to grasp because we are amusing ourselves with lies. (quoted in Zwicky, 1994)

Whenever I heard, read, or wrote narratives, meaning began to take shape. I could understand why people did what they did, that what happened to people made them the way they were. I could see the relational networks over time and space that shaped each 
self. I learned that narratives were a place where people had freedom and responsibility to tell truth, however difficult. The power of good narrative, then, lends itself particularly well to the chaotic, contextual, and complex matrices of educational research.

In 1992, I quit teaching, found a teacher, returned to school, began to write again, to read extensively, and to think deeply more than ever before. Stories began to tumble out of my pen before I was aware of what was happening and what might lie beneath the surface of those storied texts. To discover what I think, know, and understand about difficulty in teaching, I began at the beginning again, thrown back to first experiences and naive, inchoate writings. What I learned through those five years of intensive narrative research is embedded in the seven-phase method of narrative analysis I developed, that follows.

Wherever difficulty exists, there is a story behind it, often "whole, bright, and deep with meaning" (Pinar, 1981e, pp. 173-188). While we must remember that "stories are constructions that give a meaning to events and convey a particular sense of experience" (Carter, 1993, pp. 5-12), often it is the story which explains reasons enough to go on in life, however uncertainly, to keep dwelling in difficulty without giving up, and to give a semblance of significance to actions and people (Kerby, 1991).

Some of my narratives explore the underside of teaching, and some are "counternarratives" (Giroux, Lankshear, McLaren, \& Peters, 1996), which the teaching community of readers may find difficult to accept or know, and which they may prefer to leave untold. Other of my stories are memories of originary, often preconceptual, difficulty as I try (regressively) to retrace and understand my own epistemologies. Some are deliberate (progressive, synthetical) products of literary fictive craft meant to create openings for more study, multiple tellings, and diverse interpretations--as with any piece of good literature.1. All have their roots in some form of autobiography, although they may blossom into fiction. Through my "working from within" (Pinar, 1994), the truths

\footnotetext{
${ }^{1}$ Pinar's "Method of Currere," written in 1975, is one of those readings that shifts meaning each time I read it and continues to influence me. Actually doing the kind of work he advocates requires a confrontation with all of one's minotaurs in labyrinths of ever-revealing consciousness, soul, and being. It is not for the faint of heart and requires lionhearted courage. Researcher's caveat: Don't do this at home alone! You will certainly need wise mentors, a rich community of scholars both in text and in person, and perhaps thoroughgoing psychotherapy while on such research journeys. Nonetheless, I think it is a worthy curriculum journey for every teacher.
} 
which continue to be uncovered in these narratives are something much more than factual reports. All of them may serve as force-field containers (temenos) which textually hold still the shards and images of difficulty long enough to examine the site of self, especially in teaching.

What is important in researching difficulty through narrative is that the narratives constitute a kind of daily, practical, if lyric (Zwicky 1994), philosophy. These serve to ground a reflective practitioner, who is able to call one's shadow (Jungian interpretations of that term) to "heel," to leave practices of unhealthy transference outside the door? and to dwell in embodied action with one's students.

Our entire education system is in deep difficulty, but I have the right to govern only myself and must do so, reconstituting my theory which is my practice, to be able to work with others at the center of those difficulties, with a durable, intelligent, wise, humble, generative, compassionate self. Narrative research has opened a praxical answer to the questions I raised at the beginning.

Common questions asked by experienced teachers in their professional lives call for an hermeneutic research connected to the stories we tell and write about our work. We ask: "What is going on here" "Who in the world am I by now?" "Where am I and how did I get here?" "How do I go on from here?" "What interpretations can I make of my professional being and practice?" "What is called for in praxis as I construct meaning?"

My best answers to those issues still lie, in part, with strong and valid narrative research which concerns itself with stories and narrative analysis in educational research (Fowler, 2001, in progress). Narrative, at some primal level, always concerns itself structurally with issues of setting, character, plot, point of view, symbolism. Multiple resonances occur in narrative because we understand the concept of story at a fundamental, epistemological level. Although narrative appears to be the genetic code of human consciousness, I want to problematize traditional assumptions about narrative understanding and narrative research work, especially in the domain of education and

\footnotetext{
${ }^{2}$ For example, Anna Freud, Alice Miller, and, more recently, Deborah Britzman.
} 
curriculum theory. I do this by developing a method of narrative analysis as antidote to the plethora of naive, written teaching stories posing as narrative research.

I want to make a passionate plea to move beyond naïve storying, and to engage stories as narrative plains on which we construct deeper knowledge and understanding about narrative, education, and research in language and curriculum studies.

Seven interpretive gates of narrative analysis

From my fictional, autobiographical, and educational research, I recognize at least seven, significant, interconnected, recursive, interpretive gates, of narrative analysis that could be useful to researchers in education using stories, counter-narratives, narrative interviews or critical incidents in their qualitative work. These phases or gates into narrative understanding are described more thoroughly in a full text manuscript presently in review at a publisher. In very brief summary, these seven gates are:

(a) Naive storying, which requires breaking silence, finding language and voice to (pre)consciously tell an experience, image, event, conflict, or puzzlement about a difficulty that exists either in the common world or the private world. Something happened: what is being told at the elemental story level? In "The Anger in Our Miss Maple", the story just opened out, after many years of teaching, from a frustrating day of teaching in a secondary classroom. For ethical reasons, I wrote it as a fiction, but this naive storying gate is only the very beginning of narrative research.

(b) Psychological re/construction includes two main qualities: affect, which is often about the emotional knot in the narrative at hand, and cognition, an inextricably linked (superimposed) cognitive process of making sense. At this second analytical phase, the narrative researcher ask about the emotions in the story and in the reader; it also asks how one can think about the story. What emotions are evinced? What cognitive work is called for? In the "Miss Maple" story I was surprised at seeing my own anger revealed and then had to really think, What is going on here? Is this about the students, about me and my practice? These kinds of questions opened the way to thinking about the power and effect of anger at the site of the teacher.

3 This concern has arisen in a number of collegial encounters. A recent and notable example: Janet Miller referred to the too many "cheerful" stories of teaching that abound in the literature (in conversation, A pril 2000 in Baton Rouge). 
(c) Psychotherapeutic ethics, is the third gates which asks the researcher/ author/ reader (all problematic roles) to engage in issues surrounding (professional) ethics and morality. Here, we each confront our own potential for harm in teaching and research. Here we recall our shadows, owning our capacity for projection and transference, and doing honest work on our own psyche (spirit/soul/self). In "The anger in our Miss Maple" for instance, I realized some of the source difficulty through thinking about the story and paying attention to my own emotions as the writer. I then was forced to take responsibility for greater understanding of how much (often misplaced) anger I have carried at various times in my own teaching. I began to realize that not dealing with those issues increased my stress in teaching and very likely caused various forms of harm in my students who had to suffer those times when I carry unexamined anger with me. This is a very sobering experience but continues to teach me a great deal, as I examine difficulty in the safer form of story, so that I can then take the knowledge back into my own being.

(d) Narrative craft is the fourth gate which refocuses the researcher on elements of convention, structure, and craft which constitute the safe container (temenos) of story. Narrative safely holds everything in one place -- people, events, relationships, settings, and difficulty or conflict -- long enough to study them. Usually after excavating personal issues of teaching practice, as with "Miss Maple" I feel tired, surprised, concerned, but am able return to the story with a more writerly eye as I take rest from the intensity. I continue to work, but from a different angle, still productive in the research process, as author working on the story and its structure. Voice, tone, style, and the need for editing make it a more effective story, more accurate or truer in a sense to the original experience.

(e) Hermeneutic philosophy requires careful interpretive exploration of what is uncovering and revealing. This fifth gate in narrative research concerns itself with what messages might lie beneath the surface text as one moves toward opening deeper meaning, and returning to original difficulties of Being and self: What other interpretations can be made about the story in question? What is the subtext? In "Miss Maple" I ask, what is really going on in the relationship between students and teachers, what lies beneath teacher anger, how can we think about and research difficulty in 
teaching, what was the real point of difficulty in the story, what else might the ending mean, what happens when a teacher reaches a point past which he or she cannot go on or remain teaching, what is underneath reasons for leaving teaching, what causes difficulty in a classroom, how does a teacher behave when angry, what is shown in the language (angry "verbs" for instance) showing a level of violence in the teacher, and what happens when teachers "lose control", as if they had it? These questions particularly lead to the sixth gate.

(f) Curriculum pedagogy, which raises questions about what the story text offers in terms of insightful implications for teachers, for teaching, and all the contingent, contextual relational networks in teaching and learning. What curriculum does every teacher bring to every class? How does a curriculum of anger, for instance, influence what is done in classrooms and what about relations of power? When a reflective practitioner who is a competent teacher but finds himself or herself in trouble, what are the professional obligations? All this narrative work here can hopefully bring thoughtful researchers closer to improve teaching and being, moving toward a poetics in a teaching life, even when difficulty prevails.

(g) Poetics of teaching, which are not just artistic gestures to the final draft of a story let out into the public domain, but conscious reconstitution of our selves toward beauty, truth, justice, wisdom, art, and meaning while we mindfully dwell in the present moment on this planet.

I believe narrative research can serve as entry points or gates to understanding across differences, borders, and ruptures that constitute a curriculum of difficulty. These gates give us a way to explore the qualities of auto-historical and allo-historical curricula that makes possible understanding and generative co-dwelling on our shared lands and languages of being.

We need analysis of stories to make narrative research an authentic mode of educational inquiry, but narrative analysis is not for the faint of heart, certainly not for those seeking escape from quantitative research. A choice to engage in narrative research should arise out authentic research questions which can be answered with narrative understanding. It is the very difficulty itself revealed in emerging narrative which draws 
us into deeper study which can benefit ourselves, our students, our profession. In narrative and interpretive educational research, stories themselves are not enough.

\section{Bibliography and Selected References for Narrative Research}

Anderson, L. (1997). The stories teachers tell and what they tell us, Teaching and Teacher Education, 13 (1), 131-136.

Aoki, T. (1981a). Inspiriting curriculum and pedagogy: Talks to teachers. Edmonton, Alberta, Canada: University of Alberta, Faculty of Education, Publication.

Aoki, T. (Eds.). (1985). Understanding curriculum as lived: Curriculum Canada VII. Vancouver, British Columbia, Canada: University of Columbia, Faculty of Education, Centre for the Study of Curriculum and Instruction.

Aoki, T. (1986b, April/May). Teaching as in-dwelling between two curriculum worlds. The B.C. Teacher, 8-10.

Aoki, T. (1992a). Teachers narrating/narratives teaching. Victoria, British Columbia, Canada: Ministry of Education and Ministry Responsible for Multiculturalism and Human Rights, Province of British Columbia.

Aoki, T. (1992b). Layered understandings of teaching: The uncannily correct and the elusively true. In W. Pinar \& W. Reynolds (Eds.), Understanding curriculum as phenomenological and deconstructed text (17-27). New York: Columbia Teachers' Federation.

Belenky, M. et al (1986). Women's ways of knowing: The development of self, voice, and mind. New York: Basic Books.

Bleicher, J. (1980). Contemporary hermeneutics: Hermeneutics as method, philosophy, and critique. London: Routledge and Kegan Paul.

Britzman, D. (1991). Practice makes practice: A critical study of learning to teach. Albany, NY: State University of New York Press.

Britzman, D. ( 1992b). The terrible problem of knowing thyself: Toward a poststructural account of teacher identity. Journal of Curriculum Theorizing, 9 (3), 23-46.

Britzman, D. (1993). Slips that show and tell: Fashioning multiculture as a problem of representation. In C. McCarthy \& W. Crichlow (Eds.), Race, identity, and representation in education (188-200). New York: Routledge. 
Brodzki, B. and Schenck, C., Eds. (1988). Life/Lines: Theorizing women's autobiography. Ithaca and London: Cornell University Press.

Brookes, A-L. (1992). Feminist pedagogy: An autobiographical approach. Halifax: Fernwood Publishing.

Broudy, H. What knowledge is of most worth ? Educational Leadership, May 1982, 574-578.

Caputo, J. D. (1987). Radical hermeneutics: Repetition, deconstruction, and the hermeneutic project. Bloomington: Indiana University Press.

Carr, D. (1985). Life and the narrator's art. In H. Silverman and D. Ihde (Eds.), Hermeneutics and deconstruction. Albany: State University of New York Press.

Carter, K. (1993). The place of story in the study of teaching and teacher education, Educational Researcher, 22 (1), 5-12, 18.

Chamberlain, D. (1990). Narrative perspective in fiction. Toronto: University of Toronto Press.

Chambers, C. (1999). A topography for Canadian curriculum theory. Canadian Journal of Education; 24, (2), 137-150.

Chambers, R. (1984). Story and situation: Narrative seduction and the power of fiction. Minneapolis: University of Minnesota.

Champigny, R. (1972). The ontology of narrative: An analysis. The Hague: Mouton. Chatman, S. (1978). Story and discourse: Narrative structure in fiction and film. Ithaca: Cornell University Press.

Clandinin, J. \& Connelly, M. (1990). Narrative, experience and the study of curriculum.Cambridge Journal of Education, 20 (3), 241-254.

Clandinin, J. \& Connelly, M. (1991). Narrative and story in practice and research. In D.Schon (Ed.), The reflective turn: Case studies in and on educational practice (258-281). New York: Teachers College Press.

Clandinin, J. \& Connelly, M. (1999). Narrative inquiry: Experience and story in qualitative research. Etobicoke, ON: Jossey-Bass (John Wiley and Sons Canada)

Coles, R. (1989). The call of stories: Teaching and the moral imagination. Boston: Houghton Mifflin. 
Connelly, M., \& Clandinin, J. (1990). Stories of experience and narrative inquiry. Educational Researcher, 19 (5), 2-14.

Crites, S. (1971). The narrative quality of experience. In Journal of the American Academy of Religion, 39 (3).

Danto, A. (1985). Narration and knowledge. New York: Columbia University Press.

De Concini, B. (1990). Narrative remembering. Lantham, New York, London: University Press of America.

Dilthey, W. (1976). The development of hermeneutics. In Selected Writings. Ed., trans., and intro. by H.P. Rickman. Cambridge: Cambridge University Press.

Doll, W. (1993). A post-modern perspective on curriculum. New York: Teacher College Press.

Elbaz, F. (1981). The teacher's 'practical knowledge': Report of a case study. Curriculum Inquiry, 11 (1), 43-71.

Foucault, M. (1984). What is an author? In P. Rabinow, (Ed.), The Foucault reader. New York: Pantheon Books.

Fowler, L. (1989). Gifts from the tribe: The writing and teaching of five Canadian authors. Edmonton, $\mathrm{AB}$, unpublished Master of Education Thesis.

Gadamer, H-G. The hermeneutics of suspicion. In Shapiri, G., and Seed, A. (Eds.) (1984) Hermeneutics: Questions and interpretations Amherst, MA: The University of Massachussets Press.

Genette, G. (1980). Narrative discourse: An essay in method, trans, by Jane Lewin, translator; forward by Jonathan Culler. Ithaca, New York: Cornell University Press. Genette, G. (1988). Narrative discourse revisited. Ithaca, New York: Cornell University Press.

Gilligan, C. (1982). In a different voice: Psychological theory and women's development. Cambridge, MA: Harvard University Press.

Giroux, H., Lankshear, C., McLaren, P., and Peters, M. (1996). Counternarratives: Cultural studies and critical pedagogies in post-modern spaces. New York and London: Routlege. 
Goodson, I. (Ed.) (1992). Studying teachers' lives. London: Routledge.

Graham, R. (1993). Voice, archive, practice: The textual construction of professional identity. The Journal of Educational Thought, 27 (2), 186-193.

Greene, M. (1973). Teacher as stranger. Belmont, CA: Wadsworth.

Greene, M. (1987). Sense-making through story: An autobiographical inquiry. In Teaching Education: 1(2).

Grumet, M. (1981). Autobiography and reconceptualization. In H. Giroux, A. N. Penna \& W. F. Pinar, (Eds.) Curriculum and instruction. Berkeley: McCutchan.

Grumet, M. (1981). Restitution and reconstruction of educational experience: An autobiographical method for curriculum theory. In M. Lawn and L. Barton (Eds.), Rethinking curriculum studies: A radical approach. New York: John Wiley.

Grumet, M. (1988). Bitter milk: Women and teaching. Amherst: University of Massachusetts Press.

Gudmundsdottir, S. The narrative nature of pedagogical content knowledge. http://www.ipt.unit.no/jjsg/sigrun/publikasjoner/PCKNARR.html In H. McEwan and K. Egan (1995) Narrative in teaching, learning and research. New York: Teachers College Press.

Hayakawa, S. (1939). Language in thought and action. New York: Harcourt Brace Jonvanovich.

Heidegger, M. (1962). Being and time. (J. Macquarrie and E. Robinson, Trans.).New York: Harper and Row. [Original work published in 1927.]

Heilbrun, C. (1988). Writing a woman's life. New York: Ballantine.

hooks, bell. (1994). Teaching to transgress: Education as the practice of freedom. New York, London: Routledge.

Howard, Roy J. (1982). Three faces of hermeneutics: An introduction to current theories of understanding. Berkeley: University of California Press.

Hoy, P.C. (et al) (1990). Women's voices: Visions and perspectives. New York and Toronto: McGraw Hill.

Jalongo, M. and Isenberg, J. (1995) Teachers' Stories: From personal narrative to professional insight. Etobicoke, ON: John Wiley and Sons (Jossey-Bass). 
Jardine, D. (1992). Reflections on education, hermeneutics and ambiguity:

Hermeneutics as a restoring of life to its original difficulty. In W. Pinar and W. Reynolds (Eds.), Understanding Curriculum as Phenomenological and Deconstructed text. New York: Teachers College Press.

Jauss, H-R. (1982). Aesthetic experience and literary hermeneutics. Minneapolis: University of Minnesota Press. Theory and History of Literature , Vol. 3.(Especially A-5, Poiesis: the productive side of aesthetic experience (construire et connaitre; A-6, Aesthesis: the receptive side of aesthetic experience (voir plus dechoses qu'on n'en sait); A-7 Catharsis: the communicative efficacy of aesthetic experience (movere et conciliare ; A-8, Aesthetic experience among the problems of everyday life: problems of delimitation).

Jenson, D. (Ed.) (1991). Coming to writing and other essays: Helene Cixious. Cambridge: Harvard University Press.

Kerby, P. (1991). Narrative and the self. Bloomington: Indiana University Press. Kirby, S. and McKenna, K. (1989). Experience, research, social change: Methods from the margins. Toronto: Garamond Press.

Kockelmans, J. J. (1986). A companion to Martin Heidegger's "Being and time”. Washington, D. C.: Centre for Advanced Research in Phenomenology and University Press of America.

Krall, F. (1988). From the inside out: Personal history as educational research, Educational Theory: Fall, 38(4).

Le Guin, U. (1989). Dancing at the edge of the world: Thoughts on words, women, and places. New York: Harper and Row.

Lionnet, F. (1989). Autobiographical voices: Race, gender, self-portraiture. Ithaca, London: Cornell University Press.

McEwan, H. (1997). The functions of narrative and research on teaching, Teaching and Teacher Education, 13 (1), 85-92.

Miller, A. (1983). For your own good: Hidden cruelty in child-rearing and the roots of violence. New York: Farrar Straus.

Miller, A. (1988a). Banished knowledge. Frankfurt: Suhrkamp.

Miller, J. and Seller, W. (1990). Currciculum: Perspectives and practice. Toronto: Copp Clark Pitman Ltd. 
Mishler, E. G. (1986). Research interviewing: Context and narrative. Cambridge: Harvard University Press.

Mueller-Vollmer, K., (Ed.). (1985). The hermeneutics reader: Texts of the German tradition from the enlightenment to the present. Oxford: Basil Blackwell.

Noddings, N. (1989). Women and evil. Berkley: University of California Press.

Packer, M. \& Addison, R. (Eds.) (1990) Entering the circle: Hermeneutic investigation in psychology. Albany: State University of New York Press

Palmer, R. E. (1969). Thirty theses on interpretation: On the hermeneutical experience. Chapter 14 in Hermeneutics: Interpretation theory in Dilthey, Heidegger, and Gadamer. Evanston, IL: Northwestern University Press.

Palmer, R. E. (1969). Toward reopening the question: What is interpretation? In Hermeneutics. Evanston, IL: Northwestern University Press Evanston, IL: Northwestern University Press.

Pinar, W. F. (1981e). "Whole, bright, deep with understanding": Issues in autobiographical method and qualitative research. Journal of Curriculum Studies, 13(3), 173-188.

Pinar, W. F., and Reynolds, W. (1992). Understanding curriculum as phenomenological and deconstructed text. New York: Teachers College Press.

Pinar, W. F. (1994). Autobiography, politics, and sexuality: Essays in curriculum theory, 1972-1992 [Especially “The method of Currere”]. New York: Peter Lang.

Pinar, W. F., Reynolds, W. M., Slattery, P. \& Taubman, P. (1995). Understanding curriculum. New York: Peter Lang.

Polanyi, M. (1958). Personal knowledge: Towards a post-critical philosophy. Chicago: University of Chicago Press.

Polkinghorne, D. (1988). Narrative knowing and the human sciences. Albany: State University of New York Press.

Ricoeur, P. (1986). Time and narrative (Vol. 2). Chicago: The University of Chicago Press.

Rosenblatt, L. (1938). Exploration of literature: The transactional theory of literary work. New York: Appleton-Century. 
Rosenblatt, L. (1978). The reader, the text, the poem: The transactional theory of the literary work. Carbondale: Southern Illinois University Press.

Schleiermacher, D. E. The hermeneutics: Outline of the 1819 lectures in New Literary History, X (1), Autumn 1978.

Scholes, R. and Kellogg, R. (1966). The nature of narrative. New York: Oxford University Press.

Smith, D. G. (1991). The hermeneutic imagination and the pedagogic text. In Forms of Curriculum Inquiry, Edmund Short (Ed.). NY: Suny.

Weil, S. (1924). Quotations in J. Zwicky, Lyric Philosophy. Toronto: University of Toronto Press, 1992.

Witherell, C. \& Noddings, N. (Eds.) (1991). Stories lives tell: Narrative and dialogue in education. New York: Teachers College Press.

Zwicky, J. (1992). Lyric Philosophy. Toronto: University of Toronto Press. 